\title{
John Drydens Amboyna: Verfremdungen des Heroischen im Kontext des Welthandels
}

\author{
Barbara Korte
}

Als der Soziologe Werner Sombart 1915 zwischen ,Händlern' und ,Helden' unterschied, wollte er einen Beitrag zur deutschen Weltkriegspropaganda leisten und grenzte eine deutsche „heldische“ Weltanschauung und Kultur von einer englischen „händlerischen“ ab. Letztere charakterisiert er als essenziell unheroisch, da sie unfähig wäre, „sich auch nur um Handbreite über die greifbare und alltägliche ,Wirklichkeit" zu erheben". ${ }^{1}$ Sombarts Schrift ist polemisch und zeitgebunden, aber sie lenkt den Blick auf eine Beziehung, die bereits früheren Epochen zum Problem wurde, als sich deren politisches und soziales Gefüge durch den Welthandel veränderte. In der frühen Neuzeit gewannen wohlhabende Kaufleute neben etablierten Eliten zunehmend an Einfluss. Für England hält Shankar Raman zwei Konsequenzen dieser Entwicklung fest: „the relative decline in the position of the peerage and the nobility - in particular, relative to the middle landowning groups and the mercantile strata - and ,the weakening first of the financial resources and later of the prestige and influence of the Crown'."2 Damit gekoppelt war die Frage nach der Heroisierbarkeit der merkantilen Akteure im Verhältnis zur traditionell heroisierbaren Aristokratie, also die Frage nach einer Erweiterung des sozialen Geltungsbereichs des Heroischen. Dieser Beitrag wird am Beispiel von John Drydens Amboyna (1673) zeigen, dass die Bühne des 17. Jahrhunderts die sozialen Verschiebungen in der englischen Gesellschaft und die durch sie bedingten (Re-)Figurationen des Heroischen explizit verhandelte, und zwar mit den Mitteln des heroic play und seinen Referenzen auf das kulturell Andere. ,Fremde Helden' gehörten zum konventionellen, und das heißt auch aristokratischen, Personal des heroic play, das von Dryden maßgeblich konturiert wurde. ${ }^{3}$ In Amboyna aber werden Händler zu Helden, und die so entstehende Verschiebung im Heroisierungssystem führt nicht nur zu einer Beugung der Gattungsnormen, sondern bringt auch die Kategorien von Identität und Alterität sowie von Eigenem und Fremdem in Bewegung. Um die hierdurch bedingten Irritationen des Stücks und seine spezifischen Verschränkungen des Heroischen mit dem Fremden nachvollziehen zu können, sind zunächst einige Kontexte aufzurufen.

Werner Sombart: Händler und Helden. Patriotische Besinnungen. München 1915, 9.

2 Shankar Raman: Framing ,India: The Colonial Imaginary in Early Modern Culture. Stanford, CA 2002, 219.

3 John Dryden: Of Heroique Playes. In: The Works of John Dryden, Bd. 11, hg. von John Loftis und David Stuart Rodes. Berkeley 1978, 8-18. 


\section{Heldentum, Welthandel und Theater im 17. Jabrbundert}

England erfuhr in der zweiten Hälfte des 17. Jahrhunderts nach Bürgerkrieg und Restauration der Monarchie (1660) eine Rekonfiguration seiner gesellschaftlichen und politischen Situation, die in zentraler Weise Aspekte herrscherlicher Autorität betraf. Diese Rekonfiguration manifestierte sich, angesichts der traditionellen Bedeutung des Heroischen für die Identitätsbestimmung und Legitimierung aristokratischer Führungsschichten, auch in der Auseinandersetzung mit Heldentum, seiner Definition und Zuschreibbarkeit. Ein prominenter Ort dieser kulturellen Verhandlung war die Bühne der mit der Monarchie restaurierten, königlich lizenzierten Theater und hier besonders das am Epos orientierte heroic play, das von der Mitte der 1660er bis zum Ende der 1670er Jahre eine kurze Konjunktur erlebte: Im Vers (bei Dryden anfangs sogar gereimt) und in betont hohem Stil wurden in dieser Gattung heroische Eigenschaften eines aristokratischen Figurenpersonals im Konflikt zwischen Liebe und Ehre zur Schau gestellt, aber auch in ihren Erosionstendenzen reflektiert. ${ }^{4}$ Eine wichtige Rolle spielten dabei spektakuläre Effekte, die durch eine neue, aufwendige Bühnenmaschinerie ermöglicht wurden. Dass heroische Dramen häufig in ,exotischen' Szenarien angesiedelt sind, interpretiert die Forschung meist als Übertragung von Problemen der, eigenen' Gesellschaft in eine ,fremde ${ }^{6}$ Umgebung, um sie dort wie in einem Spiegel betrachten und analysieren zu können. ${ }^{5}$ Bei dieser Betrachtung ging es nicht nur um die auch nach der Restauration prekär gebliebene Autorität der Stuart-Könige, sondern auch um Fragen der translatio imperii ${ }^{6}$ da sich Englands Einfluss durch Kolonisierung und Handel im Verlauf des 17. Jahrhunderts immer weiter über den Globus in außereuropäische Gebiete ausdehnte und dabei in Konflikt mit anderen europäischen Kolonial- und Handelsmächten geriet - älteren wie Spanien und Portugal, und neuen wie den Niederlanden. Die Machtkonkurrenzen und -verschiebungen, die hier in Gang gerieten, wurden ebenfalls über Muster des Heroischen verhandelt, und mit ihren Stoffen waren Drydens bekannteste und erfolgreichste heroische Dramen für diesen Zweck bestens geeignet.

Drydens The Indian Emperour (1665) spielt zur Zeit der spanischen Eroberung Amerikas und bringt das Ende des Aztekenreichs und den Beginn der spanischen Weltherrschaft auf die Bühne. The Conquest of Granada (1670/71) inszeniert die Rückeroberung Spaniens von den Mauren. Aureng-Zebe (1675) spielt, fast zeitge-

\footnotetext{
Siehe hierzu auch den Beitrag von Christiane Hansen in diesem Band.

5 Siehe etwa folgende Standardwerke: Derek Hughes: Dryden's Heroic Plays. London [u.a.] 1981. Derek Hughes: English Drama 1660-1700. Oxford [u.a.] 1996. Nancy Klein Maguire: Regicide and Restoration: English Tragicomedy, 1660-1671. Cambridge 1992. Zur Darstellung neuer beziehungsweise elastisch gewordener Identitäten auf der Restaurationsbühne siehe auch Cynthia Lowenthal: Performing Identities on the Restoration Stage. Carbondale, IL [u.a.] 2003.

6 Siehe Bridget Orr: Poetic Plate-Fleets and Universal Monarchy. The Heroic Plays and Empire in the Restoration. In: Susan Green und Steven N. Zwicker (Hg.): John Dryden. A Tercentenary Miscellany. San Marino, CA 2001, 71-97, hier 71-72.
} 
nössisch, im indischen Mugalreich, zu dem England im 17. Jahrhundert intensive diplomatische und Handelsbeziehungen pflegte. Gerade dieses Stück verdeutlicht daher, dass es zu kurz greift, wenn man die ,Exotik heroischer Dramen nur als Allegorisierung des Eigenen interpretiert: Indien hatte für Dryden und sein Publikum auch eine sehr konkrete, materielle Fremdheit, die durch Reiseberichte detailliert, differenziert und keineswegs nur ,orientalistisch' vermittelt wurde. ${ }^{7} \mathrm{Zu}$ diesen Berichten zählte auch Drydens Hauptquelle für Aureng-Zebe, François Berniers Travels in the Mogul Empire. Dieser Reisebericht wurde 1671, bereits ein Jahr nach Erscheinen des französischen Originals, ins Englische übertragen. AurengZebe verdankte seine aktuelle Relevanz für das zeitgenössische Publikum also nicht nur der Übertragbarkeit von Personal und Handlung auf die StuartDynastie, sondern auch einem wesentlich durch Handelskontakte aufgebauten Interesse an und Wissen über Indien. Allerdings kommen in Aureng-Zebe, weil es ein prototypisch heroisches Drama mit ausschließlich aristokratischem Personal ist, Händler und merkantile Interessen weder zur Darstellung noch zur Sprache ganz im Gegensatz zu Drydens zwei Jahre früher verfassten und am Theatre Royal aufgeführten Stück Amboyna, or the Cruelty of the Dutch to the English Merchants, das historische Ereignisse auf einer ost-indischen Gewürzinsel aufgreift. ${ }^{8}$

Amboyna - auf dem Titelblatt des Erstdrucks als „A Tragedy“ ausgewiesen - hat ein Figurenpersonal, das in der Mehrzahl aus Vertretern englischer und holländischer Handelsgesellschaften besteht. Dazu gehört der Protagonist Towerson, der in der Forschung häufig als heroische Figur interpretiert wird, ${ }^{9}$ auch wenn der Text des Dramas ihn zunächst schlicht als „an Englishman, part Captain, and part Merchant" einführt. ${ }^{10}$ Gleichwohl lässt auch der Dramentext keinen Zweifel daran,

7 Siehe zum Indienbild vor 1800 etwa Jonathan Gil Harris (Hg.): Indography. Writing the ,Indian in Early Modern England. Basingstoke 2012, 3. Siehe zur Vielfalt englischer Indienbilder noch im kolonialen und protokolonialen Kontext auch Pramod K. Nayar: English Writing and India, 1600-1920. Colonizing Aesthetics (Routledge Research in Postcolonial Literatures; 18). London [u.a.] 2008. Rahul Sapra: The Limits of Orientalism. Seventeenth-Century Representations of India. Newark 2011. Speziell zur frühneuzeitlichen Reiseliteratur über Indien auch Kate Teltscher: India Inscribed. European and British Writing on India 1600-1800. Delhi [u.a.] 1995.

8 Zum weiten Verständnis von ,Indien' in der frühen Neuzeit siehe Raman: Framing ,India ‘ (Anm. 2).

9 So etwa J. Douglas Canfield: Heroes and States. On the Ideology of Restoration Tragedy. Lexington, KY 2000, 110. Siehe auch Raman: Framing ,India' (Anm. 2), 218: „The heroism of Dryden's Towerson contrasts strongly with the impression of Towerson one gleans from the minutes of the East India Company. These bureaucratic documents focus almost exclusively on his mercantile capabilities." Siehe auch Robert Markley: The Far East and the English Imagination, 1600-1730. Cambridge [u.a.] 2006, 165: Für Markley verkörpert Towerson „heroic attributes of love and honor, but they have been grafted onto a career EIC employee who seems to have cared more for profits than ideals. [...] To counter the spectre of Dutch evil [...] Dryden endows this EIC veteran with the traditional values of aristocratic honor and self-definition."

10 John Dryden: Amboyna. In: The Works of John Dryden, Bd.12, hg. von Vinton A. Dearing. Berkeley 1994, 1-77, hier I 2, 21-22. Alle folgenden Stellenangaben beziehen sich auf diese Angabe. 
dass Towerson heroische Eigenschaften besitzt und vor allem mit einer heroischen Haltung in den Tod geht, wie aus seiner letzten Äußerung hervorgeht:

[...] tell my friends I dy'd so as became a Christian and a Man; give to my brave Employers of the East India Company, the last remembrance of my faithful service; tell 'em I Seal that Service with my Blood; and dying, wish to all their Factories, and all the famous Merchants of our Isle, that Wealth their gen'rous Industry deserves; but dare not hope it with Dutch partnership. (V 1, 398-403)

Diese pathetischen Abschiedsworte, die gleich zweifach den Auftrag zur Weitergabe einer letzten Botschaft an die Nachwelt enthalten, richtet Towerson an einen anderen englischen Händler, seinen Freund Beamont. Sie heroisieren neben dem Protagonisten den gesamten englischen Überseehandel, seine Akteure und seine zentrale Institution im Indischen Ozean, die East India Company.

Eine solche Heroisierung von Händlern und Handel entsprach zur Entstehungszeit des Stücks weder Diskurstraditionen des Heroischen noch dramatischen Konventionen für die Darstellung der mittleren Stände. Bridget Orr hält fest: „The development of an oceanic, universal empire of trade was antipathetic to traditional modes of representation, which valued heroic ambition over the low avarice which was assumed to generate trade. [...] trade was remarkably resistant to heroic celebration." ${ }^{11}$ So stellte auch die Bühne des 17. Jahrhunderts Händler bevorzugt in der ,niederen ' Gattung der Komödie dar, ${ }^{12}$ und die zeitgenössische Erzählprosa - wie Richard Heads The English Rogue (1665) ${ }^{13}$ oder Aphra Behns Oroonoko $(1688)^{14}$ - zeichnete ebenfalls eher kritische als heroische Bilder der neuen Koloni-

11 Bridget Orr: Empire on the English Stage 1660-1714. Cambridge [u.a.] 2001, hier 98. Zur kontroversen zeitgenössischen Diskussion über den globalen Handel der frühen Neuzeit siehe auch die Aufsatzsammlung von Barbara Sebek und Stephen Deng (Hg.): Global Traffic. Discourses and Practices of Trade in English Literature and Culture from 1550 to 1700. Basingstoke [u.a.] 2008.

12 Zur Komödie siehe Kap. 7 in Orr: Empire on the English Stage (Anm. 11); zum weiteren Kontext auch Daniel Fulda: Schau-Spiele des Geldes. Die Komödie und die Entstehung der Marktgesellschaft von Shakespeare bis Lessing (Frühe Neuzeit; 102). Tübingen 2005.

13 Bei Head wird der von materiellen Bedürfnissen angetriebene englische ,Schelm schließlich in Indien zum Kaufmann, der den Reichtum seiner indischen Frau für den eigenen Profit nutzt: „What money was got by my wife's trade, I laid out in such commodities the country afforded, as calicoes, pepper, indigo, green ginger, etc. and sold them immediately to the ships lying in the harbour, doubling what I had laid out; so that in short time I found my stock to increase beyond expectation. Such satisfaction my black received from me, that she thought she could not do enough to please me. I was an absolute monarch in my family; she and her servants willingly condescended to be my vassals; yet though I thus enjoyed the prerogative of an husband, yet I did not lord it too much; which won so much upon my wife's affection, and those that were concerned with her, that as soon as I desired anything, it was immediately performed, with much alacrity and expedition." (Richard Head und Francis Kirkman: The English Rogue: Described in the Life of Meriton Latroon, A Witty Extravagant; being a complete history of the most eminent cheats of both sexes. London 1928, 262-263)

14 Siehe zu Oroonoko unter anderem Siraj Dean Ahmed: The Stillbirth of Capital. Enlightenment Writing and Colonial India. Stanford, CA 2012, 25: „En route from Old World court to New World colony, it replaces romance conventions with the novel-form (avant la lettre): the fabulous with the scientific, a feudal economy with a commercial one, nobility with 
alhändler. Wie zögerlich die Akteure der frühneuzeitlichen Expansion und des Handels heroisiert wurden, lässt sich nicht zuletzt an den Reiseberichten des 17. Jahrhunderts ablesen, die für die Beförderung des Handels und der Kolonisierung funktionalisiert wurden und ihre Akteure zu würdigen wussten. Aber selbst Hakluytus Posthumous, die monumentale Kompilation von Reisetexten, die Samuel Purchas 1625 auf der Grundlage seines Vorgängers Hakluyt veröffentlichte, ist mit der expliziten Bestimmung von Reisenden als „heroisch“ auffällig sparsam und reserviert diese für Personen höheren Standes und jene elisabethanischen Freibeuter, die sich gegen die Spanier auch militärisch bewährten. ${ }^{15}$ Es ist bezeichnend, dass noch Ende des 17. Jahrhunderts ein Pamphlet ausdrücklich deshalb gedruckt wurde, um der mangelnden Heroisierung Sir Francis Drakes entgegenzuwirken. ${ }^{16}$

Bezeichnenderweise vermeidet es auch Dryden in Amboyna, die von ihm heroisierten Händler tatsächlich als Helden zu bezeichnen: Die Wörter hero oder heroic treten im Text des Stücks nicht auf. Auch sonst scheint Dryden, den das Titelblatt des Erstdrucks als „Servant to his Majesty“ auswies, das prekäre heroische Element seiner Händler gleichzeitig vermitteln und verschleiern zu wollen. So wurde der Vers, in dem die heroisch gestimmten Figuren zumindest zeitweise sprechen (wie Towerson in seiner oben zitierten Abschiedsrede), in der publizierten Fassung des

merchants, honor and fidelity with profit and duplicity, and sovereign character with private interest."

15 Samuel Purchas: Hakluytus Posthumus or Purchas His Pilgrimes: Contayning a History of the World in Sea Voyages and Lande Travells by Englishmen and others, 20 Bde. Cambridge 2014 [1905]. Hier werden zwar die Tapferkeit und der Ruhm von Reisenden und Seefahrern gelegentlich benannt, aber nur in Ausnahmefällen wird ihnen explizit ,Heroizität' zugeschrieben. Drake und Raleigh werden unter den „Neptunian Heroes“ aufgelistet (Bd. XVI, 135). Die ausführlichste Heroisierung erfährt Sir Robert Shirley, der im frühen 17. Jahrhundert Botschafter Englands am persischen Hof und wie sein Bruder Anthony als Reisender berühmt war. Die Brüder werden bezeichnet als „the Honorable, I had almost said Heroike Gentlemen“ und mit Heroen der Antike verglichen: „And if the Argonauts of old, and Graecian Worthies, were worthily reputed Heroicall for Europaean exploits in Asia: what may wee thinke of the Sherley-Brethren, which not from the neerer Graecian shoares, but from beyond the European World, Et penitus toto divisis Orbe Britannis; have not coasted a little way (as did those) but pierced the very bowells of the Asian Seas and Lands, unto the Persian Centre" (Bd. X, 374). Ich danke Malena Klocke für die aufwendige Auswertung. Zwei französische Reiseberichte von Orienthändlern des späten 17. Jahrhunderts, Tavernier und Jean Chardin, bespricht Isabelle Morlin: Récits de voyages marchands dans la seconde moitié du XVIIe siècle: portrait du négociant en héros. In: Études littéraires 40: 2, 2009, 13-29. Morlin beobachtet, wie diese Texte den Status der Händler und die Anstrengungen und Erträge ihrer Reisen würdigen, allerdings weist auch sie keine explizite Verwendung der Bezeichnung ,Held' nach.

16 The English Heroe: or, Sir Francis Drake Revisited. Being a Full Account of the Dangerous Voyages, Admirable Adventures, Notable Discoveries, and Magnanimous Atchievements of that Valiant and Renoweed Commander. [...] Recommended as an Excellent Example to all Heroick and Active Spirits in these days to endeavour to benefit their Prince and Countrey, and Immortalize their Names by the like worthy Undertakings. Revised, Corrected, very much Inlarged, reduced into Chapters with Contents, and beautified with Pictures. By R.B. Licensed and Entred according to Order, March 30. 1687. London: Printed for Nath. Crouch at the Bell in the Poultrey near Cheapside, 1687. Das Pamphlet ist in der British Library einsehbar. 
Textes auf Drydens Wunsch wie Prosa gedruckt. ${ }^{17}$ Gattungsmuster des heroischen Dramas werden in Amboyna also gleichzeitig evoziert und kaschiert. ${ }^{18} \mathrm{Zudem}$ ist das Stück durch einen komödiantischen Handlungsstrang kontaminiert, in dem die Ehefrau des Spaniers Perez ihren Gatten gleichzeitig mit einem Engländer und einem Holländer betrügt. Dryden selbst wertete das Stück in der Widmung an seinen Patron, Lord Clifford of Chudley, ab: „the Subject barren, the Persons low" (5). Auch in den Augen mancher späterer Interpreten ist Amboyna wegen seiner hybriden Gattungszugehörigkeit als künstlerisches Versagen zu werten: „The play's failure is precisely a function of the difficulty Dryden faced in attempting to dramatize a sordid and brutal story of colonial commercial competition: the actors in this tragedy were merchants, not soldiers, and as such inappropriate for heroic representation. " 19 Demgegenüber soll im Folgenden argumentiert werden, dass Drydens im Kontext des Welthandels spielendes Stück gerade durch seine Abweichungen von Normen des heroischen Dramas einen komplexen und gerade in seinen Widersprüchlichkeiten aussagekräftigen Kommentar versucht: zum Verhältnis von Händler- und Heldentum, und zur Differenz beziehungsweise möglichen Konvergenz aristokratischer und merkantiler Werte. Dabei fungieren vielschichtige Konjunktionen von Eigenem und Fremden wie auch Identität und Alterität als Fokalisationspunkte, die für Drydens zeitgenössisches Publikum eine hohe Aktualität hatten.

\section{Identitäten und Alteritäten im Kontext des Kolonialbandels}

Amboyna wurde - mit unverhohlen propagandistischen Absichten ${ }^{20}$ - im Kontext des dritten Krieges zwischen England und Holland (1672-1674) verfasst und aufgeführt, also in Zusammenhang mit einem Konflikt, der vor allem um konkurrie-

17 Kommentar des Herausgebers der verwendeten Ausgabe (Anm. 10), 257. Zudem sind die Verse kaum gereimt, und das zu einer Zeit, als Dryden den Reim für seine heroischen Dramen noch nicht aufgegeben hatte.

18 Dieser wichtige Effekt des Stücks wird überlesen, wenn man es, wie der Herausgeber der verwendeten Ausgabe ([Anm. 10] 274-275), vor allem in der Tradition der älteren domestic tragedy liest, wie John Fletchers The Island Princess (uraufgeführt 1621 und in der Restaurationszeit wieder aufgeführt), dessen Handlung ebenfalls auf den Gewürzinseln angesiedelt ist. Siehe Andrew Hadfield: Literature, Travel, and Colonial Writing in the English Renaissance 1545-1625. Oxford 1998, 254-264. Raman: Framing ,India'(Anm. 2), 155-188. Jeanette N. Tran: „Does This Become You, Princess?“ East Indian Ethnopoesis in John Fletcher's The Island Princess. In: Jonathan Gil Harris (Hg.): Indography. Writing the ,Indian' in Early Modern England. Basingstoke 2012, 197-207. Carmen Nocentelli: Spice Race: The Island Princess and the Politics of Transnational Appropriation. In: PMLA 125: 3, 2010, 572-588. Michael Neill: „Material Flames“: The Space of Mercantile Fantasy in John Fletcher's The Island Princesse. In: Renaissance Drama, NS 28, 1997, 99-131. Ania Loomba: „Break her will, and bruise no bone sir": Colonial and Sexual Mastery in Fletcher's The Island Princess. In: Journal for Early Modern Cultural Studies 2: 1 (A Special Issue on Representations of Islam and the East, Spring/Summer), 2002, 68-108.

Orr: Empire on the English Stage (Anm. 11), 157.

20 Siehe unter anderem Markley: The Far East (Anm. 9), 159-161. 
rende Handelsinteressen ausgetragen wurde. ${ }^{21}$ Die Holländer werden in diesem Stück ohne Ausnahme und von Beginn an als ,Andere' der Engländer präsentiert - nämlich als deren ehrlose Gegenspieler:22 „No Map Shews Holland truer then our Play: | [...] View then their Falshoods, Rapine, Cruelty“ (Prolog 26-29). Der Epilog gipfelt in einem Verweis auf den Sieg Roms über die antike Handelsmacht Karthago, der den Englands gegen Holland antizipieren soll: „Let Caesar Live, and Carthage be subdu'd" (22). In Amboyna geht es aber nicht um einen Krieg zwischen Ländern, sondern um einen Konflikt im Jahr 1622, der vor allem jene Gesellschaften betraf, die den extrem profitablen Gewürzhandel für England und Holland betrieben: auf englischer Seite die East India Company, auf holländischer Seite die Verenigte Oost-Indische Compagnie. In diesem Handel waren Engländer und Holländer Kontrahenten, die aber die gleichen Ziele hatten und mit ähnlichen Mitteln agierten, was die Zuschreibung von Alterität komplizierte, gerade auch in der Konstellation der beiden europäischen Mächte mit dem kulturell exotischen Indien.

Da der Gewürzhandel für England und die Niederlande von nationaler Bedeutung war, ${ }^{23}$ wurden beide Handelsgesellschaften im Verlauf des 17. Jahrhunderts mit quasi-staatlichen Rechten (Kriegführung und Kolonisation) ausgestattet und hatten erhebliche Autorität. ${ }^{24} \mathrm{Zu}$ der Zeit, in der das Stück spielt, waren die Holländer im Gewürzhandel allerdings mächtiger als die Engländer ${ }^{25}$ und bescherten den Vertretern der East India Company auf Amboyna eine tiefe Demütigung: Obwohl zwischen der englischen und der holländischen Gesellschaft ein Vertrag bestand, wurden im Februar 1622 Mitglieder der englischen Faktorei auf Am-

21 In Annus Mirabilis (1667), seinem großen historisch-politischen Gedicht, hatte Dryden während des zweiten Krieges gegen Holland eine optimistische Prognose der Stuart-Herrschaft und ihrer Auswirkungen auf das Land versucht. $\mathrm{Zu}$ diesem Gedicht und seiner politischen Aussage, auch zum zeitgenössischen Handel, siehe Michael McKeon: Politics and Poetry in Restoration England: The Case of Dryden's „Annus Mirabilis“. Cambridge, MA 1975.

$22 \mathrm{Zu}$ antiholländischer Propaganda in England während der zweiten Hälfte des 17. Jahrhunderts siehe Joseph F. Stephenson: Redefining the Dutch: Dryden's Appropriation of National Images from Renaissance Drama in Amboyna. In: Restoration: Studies in English Literary Culture, 1660-1700 38: 2, 2014, 63-81.

23 Siehe Markley: The Far East (Anm. 9), 31: „Spices symbolized an ongoing transformation of the idea of surplus value: rather than a luxury, they increasingly seemed a necessity for maritime nations that made international trade a crucial component of their tax structures, financial planning, labor markets, investment strategies, and ideological self-definition. The challenge for the merchants of England, the United Provinces, and Portugal was to ensure that the extraordinary prices paid for pepper, nutmeg, mace, and cloves would offset the costs and risks of sending men, money, and ships halfway around the world and generate profits large enough to fund ongoing ventures."

Die 1657, also nach den Ereignissen auf Amboyna, erneuerte Charta verlieh der East India Company nicht nur ein festes Kapital, sondern auch Rechte, wie die holländische Gesellschaft befestigte Stationen im Indischen Ozean anlegen zu können. Siehe Ahmed: The Stillbirth of Capital (Anm. 14), 36. In der Handlung des Stücks sind es jedoch vor allem die holländischen Händler, die auf ihre Macht pochen.

25 So spricht Towerson ausdrücklich aus: „So weak are we, our Enemies so strong“ (III 3, 163). 
boyna aufgrund der Aussage eines Japaners (der selbst als Spion verdächtigt wurde) der Verschwörung und der Planung eines Angriffs auf das Fort der Holländer (das diese von den Portugiesen übernommen hatten) bezichtigt. Geständnisse wurden unter der Folter mit Wasser und Feuer erpresst, und schließlich wurden die meisten der verhafteten Engländer sowie der portugiesische - in Drydens Stück spanische - Aufseher der von den Holländern versklavten einheimischen Arbeitskräfte hingerichtet. Um den Hergang der Ereignisse wurde ein Pamphletkrieg geführt, und eines der Pamphlete, das die grausamen Folterungen mit großer Ausführlichkeit schildert, war Drydens Hauptquelle: Sir Dudley Digges' A True Relation of the Unjust, Cruell, and Barbarous Proceedings against the English at Amboyna. ${ }^{26}$ Es wurde 1624 verfasst und war auch später noch weit verbreitet, weil es in Purchas' Sammlung Eingang fand. Hier findet sich die folgende Beschreibung Amboynas und der Präsenz der europäischen Handelsgesellschaften:

This Amboyna is an Iland lying neere Seran, of the Circuit of fortie leagues, and giveth name also to some other small Islands adjacent. It beareth Cloves; for gathering and buying in wherof, the English Companie for their part had planted five severall Factories: the head and Rendevouz of all, at the Towne of Amboyna; and therin first, Master George Muschampe, and afterward Master Gabriell Towerson, their Agents, with directions over the smaller Factories at Hitto and Larica, upon the same Iland, and at Loho and Cambello, upon a point of their neighbouring Island of Seran. Upon these Ilands of Amboyna, and the point of Seran, the Hollanders have foure Forts; the chiefe of all is at the said Towne of Amboyna, and is very strong, having foure Points or Bullwarkes with their Curtaines, and upon each of these Points sixe great Pieces of Ordnance mounted, most of them Brasse. The one side of this Castle is washed by the Sea, and the other is divided from the Land with a Ditch of foure or five fathome broad, very deepe, and ever filled with the Sea. [...] Heere the English lived; not in the Castle, but under protection therof, in a house of their owne in the Towne; holding themselves safe, as well in respect of the ancient bonds of Amitie betweene both Nations, as of the strict conjunction made by the late Treatie before mentioned. 27

Schon diese Beschreibung betont die ungleichen Machtverhältnisse zwischen Engländern und Holländern. Durch die Gewalt, die ihnen später angetan wird, werden die Engländer zu Opfern; Drydens Stück stilisiert sie mit seinen Referenzen auf das heroische Drama aber zu Opfer-Helden, ${ }^{28}$ die Wertvorstellungen verkörpern, welche zu denen der Holländer in krassem Gegensatz stehen. Die angeblich fundamentale Alterität der Holländer ist die Folie, vor der die Engländer in Drydens Stück ihre eigene Identität als Welthändler definieren, wie auch Victor Raman festhält: „England and the English are characterized by an idealized disinterestedness, whose marks are generosity, gratitude, honor, heroism, and true religious faith. The

26 Die sensationalistische Beschreibung der Grausamkeiten im Pamphlet bespricht Ayanna Thompson: Performing Race and Torture on the Early Modern Stage (Routledge Studies in Renaissance Literature and Culture; 9). London 2008, 102-109.

Purchas: Hakluytus Posthumus (Anm. 15), Bd. X, 507-522, hier 507-508.

28 Zum Verhältnis von Helden und Opfern siehe Bernhard Giesen: Triumph and Trauma. Boulder, CO 2004. 
Dutch, on the other hand, incarnate a pure commercial interest that excludes all forms of faith, justice, and reciprocity. "29 Plakativ wird die Habgier der Holländer dem großzügigen, auf Teilen angelegten Handelsethos der englischen Händler entgegengestellt, etwa in einem Dialog zwischen Towerson und dem holländischen Gouverneur von Amboyna, Harman senior. ${ }^{30}$ Hier sagt Towerson ausdrücklich: „This Ile yields Spice enough for both; and Europe, Ports, and Chapmen, where to vend them" (I 1, 215-217). Wenige Zeilen später wird diese Aussage noch einmal bekräftigt:

And Sir, [...] what mean these endless jars of Trading Nations? 'tis true, the World was never large enough for Avarice and Ambition; but those who can be pleas'd with moderate gain, may have the ends of Nature, not to want: nay, even its Luxuries may be supply'd from her o'erflowing bounties in these parts: from whence she yearly sends Spices, and Gums, the Food of Heaven in Sacrifice: And besides these, her Gems of richest value, for Ornament, more than necessity. (I 1, 220-227)

Die so schon im I. Akt thematisierte heroisierte Identität der englischen Händler und ihr Kontrast zur niederen und unheroischen Gesinnung der holländischen Kaufleute sind auf komplexe Weise mit der Thematisierung kultureller Fremdheit verflochten, und hier kommt der konventionellen Figur der ,exotischen Heldin“ des heroic play eine entscheidende Rolle zu.

\section{Heldentum und Fremdheit in Amboyna}

In der Welt von Drydens Stück gibt es unter den Einheimischen Amboynas (im Gegensatz etwa zu The Indian Emperor) keinen männlichen Helden. Der prototypische ,exotische Held' des Restaurationstheaters scheint hier den Ausbeutungsprozessen des frühneuzeitlichen Handels bereits zum Opfer gefallen zu sein und existiert nur als Leerstelle. Außer einigen Tänzern, die in einer exotischen Szene zu Beginn des Dramas auftreten („Enter Amboyners, Men and Women with Timbrels before them. A Dance"), ist Ysabinda, „an Indian Lady“, wie sie im Verzeichnis der dramatis personae bezeichnet wird, die einzige indigene Figur. Sie ist in mancher Hinsicht ein ostindisches Pendant zur indianischen Pocahontas und scheint (in postkolonialer Lesart) für die Feminisierung - oder Entmännlichung - ihrer ausgebeuteten Gesellschaft zu stehen. Vor allem entspricht Ysabinda aber dem Gattungsmuster des heroic play, nämlich als schöne, aristokratische und begehrte Exotin, die den Werten von Liebe und Ehre verpflichtet ist. In dieser Hinsicht trägt sie auch zur Nobilitierung und Heroisierung des Händlers Towerson bei, denn sie hat sich für ihn entschieden, mit ihm verlobt und ist für ihn zum Christentum übergetreten. Sie ist ihm treu geblieben, obwohl Towerson nach zwölf Jahren im Dienst der East India Company ,with honor and great wealth“ (I 1, 113-114)

29 Raman: Framing, India'(Anm. 2), 203.

30 Harmans Leibesfülle und sein bezeichnender früherer Beruf als Küfner werden in I 1, 146-149 ausdrücklich hervorgehoben. 
nach England zurückgekehrt ist. Beamont betont in der 1. Szene, dass der soeben nach dreijähriger Abwesenheit - und in der Führungsposition eines „General of the Voyage" - wieder auf Amboyna eingetroffene Towerson Ysabindas Liebe verdient, denn seine fehlende aristokratische Herkunft wird durch seine charakteriche Exzellenz kompensiert:

Were I to chuse of all mankind, a Man, on whom I would relie for Faith and Counsel, or more, whose personal aid I wou'd invite, in any worthy cause to second me, it shou'd be only Gabriel Towerson; daring he is, and thereto fortunate: yet soft and apt to pitty the distress'd; and liberal to relieve 'em: [...] if he has any fault, 'tis only that, to which great minds can only subject be, he thinks all honest, 'cause himself is so, and therefore none suspects. (I 1, 125-134)

Beamont bestätigt damit Eigenschaften, die Collins, ein anderer englischer Händler, schon einige Zeilen zuvor festgestellt hat: „our honest, and our gallant Countreyman, brave Captain Gabriel Towerson" (I 1, 106-107). Mit Tapferkeit, Aufrichtigkeit und Großmut besitzt Towerson wesentliche Tugenden, die im 17. Jahrhundert für Zuschreibungen des Heroischen Voraussetzung waren.

So flammt nach seiner Rückkehr auch die Liebe des heroischen Paares sofort wieder auf, und die unmittelbare Hochzeit wird beschlossen. Allerdings ist mit Towerson auch Harman junior zurückgekehrt, der Sohn des holländischen Gouverneurs. Nach einem weiteren Muster des heroic play wird er zum Liebeskonkurrenten des Helden und versucht Ysabinda für sich zu gewinnen; sie weist sein unehrenhaftes Werben jedoch dezidiert zurück: „you've done a most unmanly and ungrateful part, to court the intended Wife of him, to whom you are most oblig'd“ (II 1,14-16). Die hier angesprochene Verpflichtung Harmans rührt daher, dass Towerson dessen Schiff gerettet hat, als es auf dem Weg nach Amboyna von Piraten angegriffen wurde. Mit dieser Tat wird Towerson auch mit der kämpferischen Tugend eines traditionellen Helden ausstaffiert, die zum Ärger seines Konkurrenten während der Hochzeitsfeierlichkeiten noch einmal aufgerufen wird, als auf Beamonts Anweisung das Lied „The Sea Fight“ vorgetragen wird, das im ursprünglichen Aufführungskontext des Stücks an den aktuellen Krieg gegen die Holländer erinnerte.

Harman ist ein unwürdiger Konkurrent für Towerson, da sein Wertsystem nicht auf die Ideale von Ehre und Ehrlichkeit gebaut ist, sondern rein auf materiellen Gewinn. Towerson ist empört, als Harman mit ihm um Ysabinda feilschen will und ihm im Tausch für sie Handelvorteile anbietet: „I never gave you just occasion to think I wou'd make Merchandise of Love“ (II 1, 81-82). Im Dreieck der Liebesbeziehung werden so, wie für die Konkurrenz im Gewürzhandel, heroische Gesinnung und merkantiles Interesse kontrastiert.

Nach der Eheschließung von Ysabinda und Towerson eskaliert der Konflikt zwischen den Rivalen und ihren jeweiligen Gemeinschaften. Harman juniors Strategie geht jetzt vom Handel zum Raub über. Er entführt die Braut vor ihrer Hochzeitsnacht und fordert sie auf, ihre Zuneigung und vor allem ihren Körper 
zwischen ihm und Towerson zu teilen: „You are a Woman; have enough of Love for him and me; I know the plenteous Harvest all is his: he has so much of joy, that he must labor under it. In charity you may allow some gleanings to a Friend" (IV 3, 30-33). Ysabinda weigert sich, wird von dem Holländer vergewaltigt, und in der 5. Szene des IV. Aktes findet Towerson seine Ehefrau geschändet und an einen Baum gefesselt. ${ }^{31}$ Ihrer Ehre beraubt und ,entwertet' fühlt sie sich ihres Ehemannes nicht mehr würdig:

Love is now no more; Look on me as thou wou'dst on some foul Leaper; and do not touch me: I am all polluted, all shame, all o're dishonour; fly my sight, and, for my sake, fly this detested Isle, where horrid Ills so black and fatal dwell, as Indians cou'd not guess, till Europe taught. (IV 5, 13-17)

Nachdem sich auf der privaten Handlungsebene brutales Besitzstreben gegenüber heroischer Liebe und Ehre durchgesetzt hat, bleibt Ysabinda nur noch die Hoffnung auf einen heroischen Tod, entweder durch die Hand des Ehemanns (was dieser verweigert) oder den Suizid, der für sie eine edle und heroische Tat ist, die sich über alltägliche Moral erheben darf. ${ }^{32} \mathrm{Da}$ ihr Towerson allerdings die Selbsttötung verbietet, stirbt Ysabinda im Gegensatz zu exotischen Heldinnen in typischen heroic plays keinen Bühnentod, sondern kündigt nur ihr baldiges Ende durch Nahrungsverweigerung an. Bleibt der Frau also nur das heroische Erdulden und Sterben, kann Towerson zur aktiven Rache schreiten, um die Schande, die ihm und seiner Frau angetan wurde, zu vergelten. Nach einigen weiteren Komplikationen der Handlung tötet er Harman junior und stirbt bald darauf selbst infolge der Intrige der Holländer gegen die englischen Händler. Wie Ysabinda wird auch ihm der Tod auf der Bühne allerdings versagt, worin man einen weiteren Versuch Drydens sehen mag, dem Händler die vollendete Heroisierung eines aristokratischen Helden zu verweigern.

In dieser groben Handlungsskizze zeigt sich die Argumentationskonstellation des Stücks: Ysabinda als prototypische, fremde Heldin' des heroic play ist Angelpunkt eines Konflikts zwischen europäischen Händlern, der über heroische Tu-

31 Zum Vergewaltigungsmotiv auf der Restaurationsbühne und seinen Bezügen zu zeitgenössischer Politik siehe Jennifer L. Airey: The Politics of Rape: Sexual Atrocity, Propaganda Wars, and the Restoration Stage. Newark, DE 2012. Instruktiv für die Interpretation der Vergewaltigung in Amboyna ist dabei der Hinweis, dass bis ins 18. Jahrhundert Vergewaltigung in England (auch) als Eigentumsdelikt galt (7). Airey liest die Vergewaltigung Ysabindas als Mittel der Dämonisierung der Holländer, aber auch als Ausdruck der Schädigung, die England durch die Holländer erfährt: „The English have ceded their position of authority to the Dutch, the colonizers becoming the colonized in India. Ysabinda's death [...] symbolizes the damage done to the English nation as the Dutch usurp English property, humiliate English men, and degrade them to the status of natives" (76). „I grant, it is its great and general Law: But as Kings, who are, or should be above Laws, dispence with 'em when levell'd at themselves; Even so may man, without offence to Heaven, dispence with what concerns himself alone: Nor is death in it self an ill; then holy Martyrs sin'd, who ran uncall'd to snatch their Martyrdom: And blessed Virgins, whom you celebrate for voluntary death, to free themselves from that which I have suffer'd“(VI 5, 53-60). 
genden verhandelt wird. Dabei vermischen sich aber Argumente, und es werden Paradoxien aufgerufen, die das Stück nicht auflösen kann. An der Oberfläche geht es um eine Diskreditierung der Holländer und Nobilitierung der Engländer. Aber gleichzeitig zu dieser Kontrastierung der Nationen werden andere, weniger eindeutige Aspekte mitverhandelt: die Interferenz von neuer Handels- und Kolonialmacht mit dem Kodex der traditionellen Standesgesellschaft sowie die Frage, wie sich die neue Rolle in der Welt auf die Identität der Engländer auswirkt. Diese sich kreuzenden Linien sollen im Folgenden genauer betrachtet werden.

Dass die staatlich sanktionierten Handelsgesellschaften des 17. Jahrhunderts über erhebliche Autorität verfügten, zeigt Drydens Stück deutlich am Beispiel der Holländer, welche die Insel Amboyna von ihrer Festung aus beherrschen, ihre Einwohner versklaven und fern von ihren Auftraggebern in Europa die Gesetze beugen. Dass auch englische Händler neue Autoritätsansprüche hatten, drückt das Stück vor allem über die Zuschreibung heroischer Eigenschaften aus, wodurch der traditionell aristokratische Geltungsanspruch des Heroischen erweitert wird. Dass Dryden es für opportun hielt, diese Erweiterung diskret anzusprechen, wurde bereits erwähnt. Die Heroisierung der Engländer dient aber vor allem dazu, sie als moralisch ,bessere Macht im Kolonialwarenhandel auszuweisen.

Die Beziehung zwischen Towerson, Harman junior und der von beiden begehrten Ysabinda ist in recht offensichtlicher Weise als Allegorie für den Wettbewerb der beiden neuen Akteure im Kolonialhandel interpretierbar: „the ,Indian woman“ becomes the site of a direct struggle between the two European powers who have taken over the mantle once worn by Spain/Portugal“. ${ }^{33}$ Dabei entspricht die Hingabe Ysabindas an Towerson einem Mythos, der den Akt der Kolonisation als Begehren der Kolonisierten erscheinen lässt und so zu legitimieren scheint: „the colonial myth of the native freely yielding him/herself up to the colonizer's protection and sovereignty" ${ }^{34} \mathrm{Zu}$ diesem Mythos passt, dass Ysabinda nicht als Amazone präsentiert wird, welche die Waffe ergreift, um sich oder andere zu verteidigen, sondern dass sie ihren heroischen Charakter nur in der Bereitschaft zum Suizid beweist. Dass sie sich gegen ihre Inbesitznahme wehren könnte, ist im Stück wie in der Ideologie des Kolonialhandels nicht angelegt. Für die Rache ihrer Schändung bedarf Ysabinda, ob als private Person oder als Allegorie der Kolonisierten, des heroischen Engländers, der die Vision einer ehrenvollen und konsensuellen Form des Kolonialhandels verkörpert - im Gegensatz zu den gierigen und gewaltsam agierenden Holländern, auf die das Stück alle Negativurteile über diesen Handel projiziert.

Allerdings macht Drydens Stück auch deutlich, dass der Gegensatz zwischen heroischen englischen Händlern und niederträchtigen holländischen Kaufleuten ein Konstrukt ist, dem die Wirklichkeit nicht standhält. Dies suggerieren sogar die 
oben bereits zitierten Worte, die Ysabinda nach ihrer Vergewaltigung an Towerson richtet und in denen sie ihre Insel beschreibt als „this detested Isle, where horrid Ills so black and fatal dwell, as Indians cou'd not guess, till Europe taught" (IV 5, 15-17). Der hier ausgesprochene Kontrast wird zwischen ,Indern' und allen Europäern gezogen. Während Ysabinda zwischen Towerson und Harman junior als Privatpersonen mit unterschiedlichen Werten sehr wohl unterscheidet, scheint sie dies für den Kolonialhandel nicht zu tun. Bezeichnenderweise ist auch das Teilen Ysabindas, das Harman junior Towerson vorschlägt und das auf privater Ebene pervers erscheint, nur eine Übertragung des gleichen Prinzips, das Towerson Harmans Vater für den Gewürzhandel vorgeschlagen hat. Solche Irritationen sind Teil der zahlreichen Widersprüche, mit denen Amboyna den Diskurs über heroische englische Händler entfaltet. So beobachtet auch Siraj Ahmed:

Even as it employs the rhetoric of aristocratic honor, Amboyna insinuates that this rhetoric is now nothing more than a disguise for mercantile interests. In other words, the play's duplicity in regard to aristocratic values inculcates a reading practice that recognizes, behind the political ideology of the aristocracy, the political economy of the monopoly state. $^{35}$

Besonders deutlich wird dies im komödiantischen Handlungsstrang des Stücks, der die Struktur des heroic play eklatant stört. Hier wird klar ausgesprochen, dass die Engländer trotz ihres heroischen Selbstverständnisses genauso handeln wie die Holländer. Der komödiantische Plot, der die heroische Haupthandlung spiegelt, hat sein eigenes Liebesdreieck zwischen Towersons Vertrautem Beamont, dem holländischen Fiskal und Julia, der (vermutlich indigenen ${ }^{36}$ ) Ehefrau des Spaniers Perez, der in holländischen Diensten steht, sich aber sein Ehrbewusstsein bewahrt hat und später mit den Engländern angeklagt wird. Die Abgrenzung der Engländer von den angeblich so anderen Holländern wird völlig aufgeweicht, wenn Beamont Julias Gatten ebenso die Hörner aufsetzt wie der Fiskal. Dryden lässt Julia dies sogar mit der Bildlichkeit des Gewürzhandels - beziehungsweise noch allgemeiner der translatio imperii von alten auf neue Kolonialmächte - kommentieren: „If my English Lover Beamont, my Dutch Love the Fiscall, and my Spanish Husband, were Painted in a piece with me amongst 'em, they wou'd make a Pretty Emblem of the two Nations, that Cuckold his Catholick Majesty in his Indies" (II 1, 226-230). Auch in anderer Hinsicht zeigt sich an Beamont, dass er trotz nobler Gesinnung gegen merkantile Prinzipien nicht immun ist. Obwohl er die Folter durch die Holländer tapfer erträgt, lässt Beamont es am Ende zu, dass er durch einen Tauschhandel gerettet wird: Als ihr Ehemann mit den Engländern hingerichtet werden soll, akzeptiert Julia das Angebot des Fiskal, sie zu heiraten, wenn dafür Beamont

35 Ahmed: The Stillbirth of Capital (Anm. 14), 41.

36 Die Quellen des Stücks legen nahe, dass Julia eine indigene Amboyanerin ist, während Drydens Text dies offen lässt. Siehe Candy B. K. Schille: „With Honour Quit the Fort“. Ambivalent Colonialism in Dryden's Amboyna. In: Early Modern Literary Studies 12: 1, 2006, 1-30, http://purl.oclc.org/emls/12-1/schiambo.htm, 29. März 2016. 
vom Tod verschont bleibt. Immer wieder scheint so die profane Welt des Handels durch die Folie heroischer Werte und Ideale hindurch. Nicht einmal Towersons heroischer Habitus kann sich wegen seiner Rücksichten auf die East India Company immer voll entfalten. Als er in der 1. Szene des II. Aktes im Wettbewerb um Ysabinda von Harman junior zum Duell herausgefordert wird, lehnt er dies mit Verweis auf seine offizielle Funktion ab; er ist hier offensichtlich kein autonom agierender Held, sondern unterwirft sich institutionalisierten Autoritäten:

I'm not to be provok'd out of my temper: here I am a Publick Person, intrusted by my King and my Employers, and shou'd I kill you Harman, [...] I shou'd betray my Countreymen to suffer not only worse Indignities, then those they have already born, but for ought I know, might give 'em up to general Imprisonment, perhaps betray them to a Massacre. (II 1, 111-118)

Auch wenn Amboyna mit Towerson einen Händler zum Helden macht und so andeutet, dass Standesverhältnisse und mit ihnen Heroisierungssysteme durchlässig geworden sind, transportiert das Stück gleichzeitig die Skepsis, ob das Heroische in einer Welt, in der Handelsgesellschaften und materielle Werte den Ton angeben, überhaupt noch ein valides Ethos ist. Zumindest ist dieses Ethos im Stück beschränkt und prekär. So erscheint Towersons Vertrauen auf Ehre mehrfach als naive und fatale Gutgläubigkeit, und Beamont stellt sogar explizit fest: „Towerson is easy, and too credulous" (III 2, 112). ${ }^{37}$ Sein heroischer, am Adel modellierter Habitus wirkt anachronistisch, so wie auch Ysabindas Glaube an Liebe und Ehre nach der Eroberung ihrer Insel durch den Handel überholt scheint. Laura Brown konstatiert deshalb eine heroische Nostalgie, die Amboyna (wie auch andere Dramen Drydens mit imperialer Thematik) durchzieht. ${ }^{38}$ Die Handlung, die sich in diesem Stück um das Heroische entfaltet, mit einer ,fremden Heldin' im Zentrum des Konflikts, steckt also voller Paradoxien und Ambivalenzen, die für England als Gesellschaft im Wandel und im Lichte der gesellschaftlichen Verschiebungen Ende des 17. Jahrhunderts kennzeichnend sind. Es ist daher konsequent, dass Amboyna in seinem letzten Akt auch ein bühnenästhetisch hoch wirksames Versatzstück des exotisch-heroischen Theaters ambivalent verwendet. Die Bühnenanweisung zur einzigen Szene des V. Aktes schreibt vor: „The Scene opens, and discovers the English Tortur'd, and the Dutch tormenting them." In diesem Szenario wird das irritierende Verhältnis von Identität und Alterität, Eigenem und Fremdem theatralisch und konkret körperlich auf den Punkt gebracht.

37 Siehe auch Ahmed: The Stillbirth of Capital (Anm. 14), 41: „The tragic flaw that eventually leads Towerson to his own execution is a peculiary aristocratic one: an ethical naïveté or credulity, a fidelty to the word, which conventionally characterizes the nobility and which the rise of merchant cunning throws into stark relief." Später findet sich dieselbe naive Gutgläubigkeit in der Figur des anachronistisch-heroischen Bacon in Aphra Behns The Widow Ranter sowie der Titelfigur ihres Romans Oroonoko. Siehe hierzu Barbara Korte: Aphra Behn's The Widow Ranter. Theatrical Heroics in a Strange New World. In: Anglia, 2015, 11-17.

38 Laura Brown: Dryden and the Imperial Imagination. In: Steven N. Zwicker (Hg.): The Cambridge Companion to John Dryden. Cambridge 2004, 59-74, hier 70. 


\section{Der verfremdete Heldenkörper}

Das heroic play des späten 17. Jahrhunderts wird nicht selten auch zum Theater der Grausamkeit. Dies erweist sich kaum eindringlicher als in den Folterszenen, die zum Repertoire dieser Stücke gehörten. Dass elaborierte Folterungen nun auf der Bühne und nicht off-stage stattfanden, hatte zumindest teilweise auch den Grund, dass sich mit den Bühnenmaschinerien der neuen Restaurationstheater solche Prozeduren spektakulär inszenieren ließen. In der Standardkonstellation wird dabei eine für Folterer und Publikum ethnisch fremde Figur gequält, wie etwa der Aztekenherrscher Montezuma in Drydens Indian Emperour, der im Ertragen der Tortur seine heroische Haltung beweist. Für Ayanna Thompson vollzieht sich in solchen Szenen eine drastische Zuschaustellung von Fremdheit:

Highlighting their outward racial differences, the rack displaced these foreign bodies in extremely open, exposed, and vulnerable ways. Victims were often stripped of most of their clothing, and if one imagines the stage rack as holding the victim up vertically to be seen by the audience, the intense focus on the stretched and controlled body is even more vivid. ${ }^{39}$

Gerade die Folterszene aus The Indian Emperour dürfte dem Publikum von Amboyna noch im Gedächtnis gewesen sein, denn dieses Stück war bis Ende des Jahrhunderts populär, ${ }^{40}$ und es bestand ein Bezug über die Besetzung, da Michael Mohun, der Towerson spielte, einige Jahre zuvor Montezuma verkörpert hatte. ${ }^{41}$ Aphra Behn griff die Standardkonstellation der Folterszene in Oroonoko auf und ließ ihren „royal slave“ in Surinam die Verstümmelung seines Körpers heroisch erdulden. ${ }^{42}$ Von dieser Standardkonstellation weicht Amboyna allerdings signifikant

39 Thompson: Performing Race and Torture (Anm. 26), 15. Siehe auch Orr: Empire on the English Stage (Anm. 11), 59: „The machinery was not simply aesthetically effective: it functioned as an index of political, technological and cultural command in the world beyond Europe so often represented on the stage."

40 Siehe den Kommentar des Herausgebers zu The Indian Emperour in: The Works of John Dryden, Bd. 9, hg. von John Loftis. Berkeley 1966, 293-330, hier 294: „The success was lasting: for more than seventy years the play maintained a place in the repertories of the London theaters. [...] We may infer that it was performed frequently in the later seventeenth century because it was often reprinted and because in the early eighteenth century (when daily theatrical notices began to appear in the newspapers) it was still popular." Ebd., 269.

42 Aphra Behn: Oroonoko. In: The Works of Aphra Behn, Bd. 3: The Fair Jilt and Other Short Stories, hg. von Janet Todd. London 1995, 50-119, hier 118: „He had learn'd to take Tobaco; and when he was assur'd he should Dye, he desir'd they would give him a Pipe in his Mouth, ready Lighted; which they did; And the Executioner came, and first cut off his Members, and then threw them into the Fire; after that, with an ill-favoured knife, they cut his Ears, and his Nose, and burn'd them; he still Smoak'd on, as if nothing had touch'd him; then they hack'd off one of his Arms, and still he bore up, and held his Pipe; but at the cutting of this other Arm, his Head Sunk, and his Pipe drop'd; and he gave up the Ghost, without a Groan, or a Reproach." In Southernes Adaptation von Behns Erzählung (1695 aufgeführt und veröffentlicht) wird diese Folterung nicht übernommen. Oroonoko stirbt hier durch eigene Hand. 
ab. Zwar werden auch hier heroische Figuren gequält, aber sowohl Folterer als auch Gefolterte sind Europäer. Es besteht zwischen ihnen also keine ethnische Differenz, und Towerson klagt die Holländer auch explizit dafür an, dass sie die Engländer wie Einheimische behandeln und damit gewissermaßen zu Fremden machen: „we are not here your Subjects, but your Partners; and that Supremacy of power you claim, extends but to the Natives, not to us" (V 1, 265-268).

Die Behandlung wie versklavte natives soll die Engländer erniedrigen. Dies wird für das Publikum aber dadurch konterkariert, dass sie die Folter ebenso tapfer ertragen wie die konventionellen fremden Helden des Theaters und dadurch nobilitiert werden. Die heroische Performanz der englischen Händler kulminiert in $\mathrm{Am}$ boyna in dem Moment, als Beamont mit Brennstäben an den Händen auf die Bühne geführt wird:

Courage my friend, and rather praise we Heaven, that it has chose two such as you and me, who will not shame our Countrey with our pains, but stand like Marble Statues in their fires, scorch'd and defac'd perhaps, not melted down. So let 'em burn this Tenement of Earth; they can but burn me naked to my soul that's of a Nobler frame, and will stand Firme, Upright, and Unconsum'd. [...] Do, I'll enjoy the Flames like Scavola; and when one's roasted, give the other hand. (V 1, 331-345)

Towerson wird auf der Bühne nicht gefoltert, was man als weiteres Indiz dafür lesen kann, dass Dryden davor zurückschreckt, diesen Händler mit allen Mitteln des konventionellen Repertoires zu heroisieren. In der Handlung wird Towerson jedoch der seelischen Grausamkeit ausgesetzt, seine Landmänner leiden sehen zu müssen - während Harman senior und der Fiskal das Schauspiel unter Konsum von Alkohol und Tabak genießen. Als ,Zuschauer dieses Schauspiels auf der Bühne kommt Towerson die Funktion zu, die Wirkung der Folter meta-theatralisch zu kommentieren und dem Publikum vor der Bühne eine empathische Rezeption als angemessen auszuweisen - eine Empathie, welche die englischen Figuren und ihr englisches Publikum gegen die gefühllosen Holländer eint:

I could weep tears of Blood to view this usage; but you, as if not made of the same Mould, see with dry eyes the Miseries of Men, as they were Creatures of another kind, not Christians, nor Allies, nor Partners with you, but as if Beasts, transfix'd on Theatres, to make you cruel sport. (V 1, 319-324) ${ }^{43}$

Gerade dieses Zitat verdeutlicht, wie vielschichtig die Alterisierungs- und Verfremdungseffekte sind, die in der Folterszene von Amboyna transportiert werden: Die Engländer werden hier wie natives im Kolonialhandel behandelt, agieren aber wie exotische Helden des Theaters. Die holländischen Folterer wiederum werden alterisiert, weil sie sich an Menschen vergehen, die eigentlich so sind wie sie selbst. ${ }^{44}$ Und schließlich lässt der von Towerson gesprochene Text noch eine weitere Facette der Alterisierung anklingen, wenn er feststellt, dass die Folter mit Wasser und

43 Siehe ähnlich auch einige Zeilen später: „We have friends in England who wou'd weep to see this acted on a Theatre, which here you make your pastime" (V 1, 368-369).

Siehe Thompson: Performing Race and Torture (Anm. 26), 15. 
Feuer die menschliche Form der Engländer in einer Weise verändert, dass sie sogar ihrer Art entfremdet scheinen: „as they were Creatures of another kind“ (V 1, 321-322). ${ }^{45}$ Die hier aufscheinende Verfremdung, oder gar Entfremdung, lässt zumindest anklingen, mit welchen Kosten für die eigene Identität der Aufstieg Englands zu einer globalen Handelsmacht verbunden sein könnte.

Wie erwähnt, ist Amboyna wegen der vielen hier zum Ausdruck kommenden Widersprüche und Ambivalenzen als künstlerisches Versagen gewertet worden. Aber gerade in der ,unreinen' Gattungszugehörigkeit des Stücks liegt auch ein besonderes semantisches Potenzial. Richard Kroll betrachtet Drydens heroic plays als Tragikomödien, die sich wegen ihrer generischen Indeterminiertheit in besonderer Weise für Gedankenexperimente eignen und Inkommensurablem Ausdruck verleihen können: „these plays - often spoken of as ,tragicomedies' - became, for Dryden and others, heuristic devices by which their age could deliberate on issues which were for it the profoundest sources of anxiety. "46 Für Amboyna und seine Mischung aus heroic play und Komödie scheint dies umso mehr zu gelten. Mit seinen Abweichungen von Konventionen des heroic play, seinen irritierenden Differenzen und Konvergenzen - von Händlern und Helden und von Eigenem und Fremdem - lässt sich Amboyna als künstlerische Reaktion auf eine politisch und gesellschaftlich instabile Situation lesen, die durch Schwächen der herrschenden Dynastie ebenso bedingt wurde wie durch die Transformation Englands zu einem global player im Handel und in der Kolonisation.

45 So auch in Towersons Rede an Beamont: „Let me embrace you while you are a Man, now you must lose that form; be parch'd and rivel'd like a dry'd Mummy, or dead Malefactor, expos'd in Chains, and blown about by Winds" (V 1, 346-349).

46 Richard Kroll: Restoration Drama and „The Circle of Commerce“: Tragicomedy, Politics, and Trade in the Seventeenth Century. Cambridge 2007, 3. 
